Volume 54

$10-13-2017$

\title{
Unreasonable Disagreement?: Judicial-Executive Exchanges about Charter Reasonableness in the Harper Era
}

Matthew A. Hennigar

Brock University

Follow this and additional works at: https://digitalcommons.osgoode.yorku.ca/ohlj

Part of the Constitutional Law Commons, and the Criminal Law Commons

Article

\section{(c) (1) $(9)$}

This work is licensed under a Creative Commons Attribution-Noncommercial-No Derivative Works 4.0 License.

\section{Citation Information}

Hennigar, Matthew A.. "Unreasonable Disagreement?: Judicial-Executive Exchanges about Charter Reasonableness in the Harper Era." Osgoode Hall Law Journal 54.4 (2017) : 1245-1274.

https://digitalcommons.osgoode.yorku.ca/ohlj/vol54/iss4/11

This Article is brought to you for free and open access by the Journals at Osgoode Digital Commons. It has been accepted for inclusion in Osgoode Hall Law Journal by an authorized editor of Osgoode Digital Commons. 


\title{
Unreasonable Disagreement?: Judicial-Executive Exchanges about Charter Reasonableness in the Harper Era
}

\begin{abstract}
Assessments of "reasonableness" are central to adjudicating claims under several Charter rights and the section 1 "reasonable limits" clause. By comparing Supreme Court of Canada rulings to facta submitted by the Attorney General of Canada to the Court, this article examines the federal government's success under Prime Minister Harper at persuading the Supreme Court of Canada that its Charter infringements in the area of criminal justice policy are reasonable, and when they fail to do so, on what grounds. The evidence reveals that the Conservative government adopted a consistently defensive posture in court, never conceding that a law was unreasonable, and that this government was almost never able to defend an impugned criminal justice law under section 1. While several of those losses concerned pre-Harper era laws, the Court did reject several Conservative criminal justice policies, most notably some mandatory minimum sentencing laws. The article's novel systematic analysis also shows that the Court sometimes rejected the federal government's characterization of the legislative objective.
\end{abstract}

\section{Keywords}

Canada. Supreme Court; Canada. Canadian Charter of Rights and Freedoms; Judicial review; Criminal law; Canada

\section{Creative Commons License} (c) (i) $\Theta$

This work is licensed under a Creative Commons Attribution-Noncommercial-No Derivative Works 4.0 License.

\section{Cover Page Footnote}

The author thanks various colleagues for feedback on previous drafts of this article, and the editor and anonymous reviewers for their constructive suggestions. The views expressed and any errors are the author's alone. 


\title{
Unreasonable Disagreement?: Judicial-Executive Exchanges about Charter Reasonableness in the Harper Era
}

\author{
MATTHEW A. HENNIGAR*
}

\begin{abstract}
Assessments of "reasonableness" are central to adjudicating claims under several Charter rights and the section 1 "reasonable limits" clause. By comparing Supreme Court of Canada rulings to facta submitted by the Attorney General of Canada to the Court, this article examines the federal government's success under Prime Minister Harper at persuading the Supreme Court of Canada that its Charter infringements in the area of criminal justice policy are reasonable, and when they fail to do so, on what grounds. The evidence reveals that the Conservative government adopted a consistently defensive posture in court, never conceding that a law was unreasonable, and that this government was almost never able to defend an impugned criminal justice law under section 1. While several of those losses concerned pre-Harper era laws, the Court did reject several Conservative criminal justice policies, most notably some mandatory minimum sentencing laws. The article's novel systematic analysis also shows that the Court sometimes rejected the federal government's characterization of the legislative objective.
\end{abstract}

L'évaluation du « caractère raisonnable » est essentielle pour statuer sur les revendications formulées à l'égard de plusieurs droits conférés par la Charte et conformément à la clause sur les limites « raisonnables » figurant à l'article 1. En comparant les décisions de la Cour suprême du Canada à l'égard des mémoires présentés par le procureur général du Canada, cet article analyse les succès remportés par le gouvernement fédéral du premier ministre Stephen Harper pour persuader la Cour du caractère raisonnable de ses infractions à la

* Associate Professor of Political Science, Brock University. The author thanks various colleagues for feedback on previous drafts of this article, and the editor and anonymous reviewers for their constructive suggestions. The views expressed and any errors are the author's alone. 
Charte dans le domaine de la justice pénale et, en cas d'échec, les motifs invoqués. Les données montrent que le gouvernement conservateur a systématiquement adopté une attitude défensive devant les tribunaux, qu'il n'a jamais reconnu le caractère déraisonnable d'une loi et qu'il n'a pratiquement jamais été capable de défendre une loi de justice pénale contestée en vertu de l'article 1. Si plusieurs de ces défaites portaient sur des lois adoptées avant l'ère Harper, la Cour a rejeté plusieurs politiques de justice pénale édictées par les conservateurs, notamment des lois sur les peines minimums obligatoires. L'analyse systématique innovante de cet article montre également que la Cour a parfois rejeté l'interprétation, par le gouvernement fédéral, de l'objectif législatif.

I. THEORETICAL BACKGROUND

II. THE SECTION 1 'REASONABLE LIMITS' CLAUSE, AND INTERNALLY LIMITED RIGHTS

III. METHODOLOGY

\section{AS SCHOLARS SUCH AS JEREMY WALDRON AND PETER RUSSELL HAVE} ARGUED — and as high court judges illustrate in their divided rulings — it is often the case that reasonable people can reasonably disagree about what constitutional rights require. ${ }^{1}$ Reasonable disagreement can occur over what is protected by any given right, but in the Canadian context, the Charter of Rights and Freedoms ${ }^{2}$ makes it explicit that that there are times when even rights violations are reasonable; indeed, this caveat is made explicit in the document's very first section. Similarly, reasonableness is central - either explicitly or implicitly — to the very definition of several Charter rights, such as the section 8 right against "unreasonable search and seizure," many of the "principles of fundamental justice" in section 7 , and the section 12 right against "cruel and unusual punishment." As such, much of the legal argumentation that takes place in cases involving rights-based challenges to the constitutionality of legislation or regulations is an attempt by the government to persuade judges that what the law is doing is reasonable.

The purpose of this paper is to assess how the Harper government's arguments about the reasonableness of federal criminal justice policies vis-à-vis the Charter fared in the Supreme Court of Canada (SCC). Criminal justice policy was chosen as the focus because "law and order" occupied a central place in the Conservative government's platform under Prime Minister Stephen Harper, and represents

1. Jeremy Waldron, Law and Disagreement (Oxford: Oxford University Press, 1999); Peter H Russell, "The Political Purposes of the Canadian Charter of Rights and Freedoms" (1983) 61:1 Can Bar Rev 30.

2. Canadian Charter of Rights and Freedoms, Part I of the Constitution Act, 1982, being Schedule B to the Canada Act 1982 (UK), 1982, c 11 [Charter]. 
a significant proportion of that government's legislative output. We also know that the Harper government had a number of high-profile losses in criminal-law cases-regarding such issues as prostitution, assisted dying, and mandatory minimum sentences - and that these represent, at some level, the inability of the government to persuade the justices that Parliament's or the executive branch's actions were reasonable. But how representative were these losses, and why did the government lose in those cases — or win, in the others? This article examines the federal government's track record in the SCC when arguing that its laws do not infringe the Charter, or that any such limitations are reasonable under section 1, and analyzes the basis of the Court's decisions when it rejected the government's arguments.

\section{THEORETICAL BACKGROUND}

The literature most closely related to the present study is that concerning "litigative dialogue." 3 For a time around the turn of this century, there was a vigorous debate in Canada about whether there was a "dialogue" between the judicial and elected branches over what the Charter requires of public policy. ${ }^{4}$ While that debate focused almost exclusively on legislative sequels to SCC rulings, it was also pointed out that there are important inter-branch exchanges over constitutional meaning that take place in the context of litigation, or "litigative dialogue." The Supreme Court has since abandoned the metaphorical framework of "dialogue," and the empirical case for dialogue based on legislative sequels has been significantly weakened by critics. ${ }^{6}$ Further, as Emmett Macfarlane argues

3. Matthew A Hennigar, "Expanding the "Dialogue" Debate: Canadian Federal Government Responses to Lower Court Charter Decisions" (2004) 37:1 Can J Pol Sci 3 [Hennigar, "Expanding the 'Dialogue' Debate"].

4. See e.g. Peter W Hogg \& Allison A Bushell, "The Charter Dialogue between Courts and Legislatures: Or Perhaps the Charter of Rights Isn't Such a Bad Thing After All” (1997) 35 Osgoode Hall LJ 75; Christopher P Manfredi \& James B Kelly, "Six Degrees of Dialogue: A Response to Hogg and Bushell” (1999) 37:3 Osgoode Hall LJ 513; FL Morton, "Dialogue or Monologue?" in Paul Howe \& Peter H Russell, eds, Judicial Power and Canadian Democracy (Montreal: McGill-Queen's University Press for the Institute for Research on Public Policy, 2001) 111; Kent Roach, The Supreme Court on Trial: Judicial Activism or Democratic Dialogue (Toronto: Irwin Law, 2001).

5. Christopher P Manfredi, "The Day the Dialogue Died: A Comment on Savvé v. Canada" (2007) 45:1 Osgoode Hall LJ 105.

6. Manfredi \& Kelly, "Six Degrees of Dialogue," supra note 4; Emmett Macfarlane, "Dialogue or compliance? Measuring legislatures' policy responses to court rulings on rights" (2013) 34:1 Int'l Pol Sci Rev 39. 
persuasively, the vigorous disagreements about whether "dialogue" is either a suitable metaphor or empirically accurate-the "dialogue about dialogue"suggest that its utility as a conceptual framework for inter-branch relations is close to nil. ${ }^{7}$ Moreover, the dialogue metaphor as applied to litigation always suffered from the serious problem that it obscures the profoundly unequal power relationship in the courtroom between judges and governments as litigants. ${ }^{8}$ Judges, as their title suggests, sit in judgment over the parties before them, and-notwithstanding the arguments of coordinate constructionists-enjoy widely-accepted dominance over constitutional interpretation and enforcement. As such, it seems prudent to avoid the metaphor entirely and, rather than attempt to revive the notion of "litigative dialogue," this article simply aims to better understand the interactions between the political executive and the judiciary in the context of constitutional litigation.

Those interactions have three dimensions worth highlighting. First, as noted, they are power laden, with the Court enjoying the upper hand. Second, and related to this, constitutional litigation is a persuasive exercise for a government, in that the objective is to convince the justices to agree with the government's position. Third, it is a justificatory exercise, as the government attempts to justify its actions (principally, to the judges) and the judges explain the rationale for their ruling. The paper provides the first detailed picture of the Harper government's efforts to justify federal criminal justice policies to the Court, its success in that endeavour, and how the Court articulated its responses. Importantly, unlike some commentators who rely on the Court's characterization of the government's position, ${ }^{9}$ this study employs the official arguments submitted by the government of Canada to ascertain its position in the cases. As we will see, this approach is superior as it avoids the omissions — and sometimes mischaracterizations — of the government's arguments by the justices.

7. Emmett Macfarlane, "Conceptual Precision and Parliamentary Systems of Rights:

Disambiguating "Dialogue"” (2012) 17:2 Rev Const Stud 73 at 76, 100.

8. Hennigar, "Expanding the 'Dialogue' Debate," supra note 3.

9. CfHamish Stewart, "Bedford and the Structure of Section 7" (2015) 60:3 McGill LJ 575 [Stewart, "Bedford and the Structure of Section 7"]. 


\section{THE SECTION 1 'REASONABLE LIMITS’ CLAUSE, AND INTERNALLY LIMITED RIGHTS}

As much of the analysis that follows concerns arguments regarding section 1 of the Charter, it is worth briefly reviewing this provision and its interpretation by the SCC.

1. The Canadian Charter of Rights and Freedoms guarantees the rights and freedoms set out in it subject only to such reasonable limits prescribed by law as can be demonstrably justified in a free and democratic society. ${ }^{10}$

That section 1 requires limits on rights to be "prescribed by law" has been interpreted to exclude rights violations caused by the discretionary behaviour of bureaucratic officials, Crowns, or police. Rather, section 1 is only available when the infringement is caused by a statute passed by Parliament or a provincial legislature, or a regulation issued by a Cabinet. ${ }^{11}$

In $R v$ Oakes, ${ }^{12}$ the SCC interpreted section 1 as requiring that the government demonstrate a "pressing and substantial objective" for a rights infringement, and that this objective be "proportional" to the infringement: That is, that the objective and infringement be "rationally connected"; that the means used "minimally impair" rights (changed almost immediately in $R v$ Edwards Books \& Art Ltd. ${ }^{13}$ to "as little as is reasonably possible"); and, since 1994, that the broader benefits of the impugned law outweigh the deleterious effects on rights-holders. If the government cannot prove to the court, "on the balance of probabilities," that the law's objective is pressing and substantial, the law cannot be upheld under section 1, regardless of proportionality considerations. Judges, however, usually defer to governments at this initial stage of the Oakes test. ${ }^{14}$

10. Charter, supra note 2, s 1 .

11. Heather MacIvor, Canadian Politics and Government in the Charter Era, 2nd ed (Don Mills, ON: Oxford University Press, 2013) at 78.

12. Rv Oakes, [1986] 1 SCR 103 at paras 69-71, 26 DLR (4th) 200 [Oakes].

13. $R v$ Edwards Books and Art Ltd, [1986] 2 SCR 713 at para 122, 35 DLR (4th) 1.

14. Peter W Hogg, "Section 1 Revisited" (1991-1992) 1 Nat'l J Const L 1; Janet Hiebert, Limiting Rights: The Dilemma of Judicial Review (Montreal: McGill-Queen's University Press, 1996). 
When impugned laws cannot be sustained under section 1 it is therefore most often because of proportionality issues, in particular "minimal impairment." 15

It is important to emphasize, in keeping with the point above, that the application of the reasonable limits test is primarily a justificatory exercise for government to judges. Then-Justice McLachlin's characterization of the test in RJR-MacDonald $v$ Canada underlines this fact: "The courts must ... insist that before the state can override constitutional rights, there be a reasoned demonstration of the good which the law may achieve in relation to the seriousness of the infringement." ${ }^{16}$ She concludes, "[i]n short, s. 1 is an exercise based on the facts of the law at issue and the proof offered of its justification, not on abstractions." ${ }^{17}$ As we shall see, some recent cases raise questions about how much section 1 analysis turns on "facts" and "proof" rather than "abstractions."

There is a complex relationship between section 1 and those rights with internal limits that implicate reasonableness, and historically the Court suggested that laws that infringe such rights would be nearly impossible to defend under section $1 .{ }^{18}$ Some examples include section 8's right against unreasonable search and seizures, and section 12's right against "cruel and unusual punishment," which the SCC has interpreted, starting in $R v$ Smith $^{19}$ as a punishment that is "grossly disproportionate" to the valid penal purpose. As we will see, almost every case in this study concerned the internally limited section 7; its unusual structure and relationship to section 1 thus merits some elaboration.

Section 7 contains a very prominent internal limit, one that has arguably come to outweigh the rights themselves in importance:

7. Everyone has the right to life, liberty, and security of the person and the right not to be deprived thereof except in accordance with the principles of fundamental justice. ${ }^{20}$

15. For a summary of the SCC's development of the Oakes test, see James B Kelly, Governing with the Charter: Legislative and Judicial Activism and Framers' Intent (Vancouver: UBC Press, 2005) at 139-44. For a more detailed account, see Sujit Choudhry, "So What is the Real Legacy of Oakes? Two Decades of Proportionality Analysis under the Canadian Charter's Section 1" (2006) 34 SCLR (2d) 501; Alana Klein, "The Arbitrariness in 'Arbitrariness' (And Overbreadth and Gross Disproportionality): Principle and Democracy in Section 7 of the Charter" (2013) 63 SCLR (2d) 377 at 391-96.

16. RJR-MacDonald v Canada, [1995] 3 SCR 199 at para 129, 127 DLR (4th) 1.

17. Ibid at para 133 .

18. Hamish Stewart, Fundamental Justice: Section 7 of the Canadian Charter of Rights and Freedoms (Toronto: Irwin Law 2012) at 289-90 [Stewart, Fundamental Justice].

19. $R v$ Smith (Edward Dewey), [1987] 1 SCR 1045, 40 DLR (4th) 435.

20. Charter, supra note 2, s 7 [emphasis added]. 
In other words, a law (or any other state action) only infringes section 7 if it deprives someone of life, liberty, or security of the person in a manner that is not consistent with the "principles of fundamental justice." In effect, this adds another hurdle for claimants under section 7 , as it requires them to demonstrate not only the prima facie limit but also to explain to the court why the limit is fundamentally unjust. Only after the claimant has met this evidentiary burden is the section 1 reasonable limits clause engaged, with the burden of proof shifting to the state.

The principles of fundamental justice are notoriously left undefined by the Charter, and have been developed by judges incrementally on a case-by-case basis. Among the over-two-dozen identified by Hamish Stewart by 2012, ${ }^{21}$ three key principles have emerged since Malmo-Levine:22 arbitrariness, overbreadth, and gross disproportionality, all of which have been described as "failures of instrumental rationality" ${ }^{23}$ - and rationality is an inherent dimension of reasonableness. The Court reviewed these concepts at some length in Bedford, when the Court clarified that all three are conceptually distinct and not simply different dimensions of overbreadth: ${ }^{24}$

Arbitrariness asks whether there is a direct connection between the purpose of the law and the impugned effect on the individual, in the sense that the effect on the individual bears some relation to the law's purpose. ... Overbreadth deals with a law that is so broad in scope that it includes some conduct that bears no relation to its purpose. In this sense, the law is arbitrary in part. At its core, overbreadth addresses the situation where there is no rational connection between the purposes of the law and some, but not all, of its impacts. ... Gross disproportionality ... targets ... the second fundamental evil: the law's effects on life, liberty or security of the person are so grossly disproportionate to its purposes that they cannot rationally be supported. The rule against gross disproportionality only applies in extreme cases where the seriousness of the deprivation is totally out of sync with the objective of the measure. ${ }^{25}$

Prior to Bedford, it was widely held that laws incompatible with these three principles could not be sustained under section 1-after all, how could a law that was so arbitrary, overbroad, or grossly disproportionate as to be fundamentally

21. Stewart, Fundamental Justice, supra note 18, ch 4-5. See also, Peter Hogg, "The Brilliant Career of Section 7 of the Charter" (2012) 58 SCLR (2d) 195.

22. $R v$ Malmo-Levine; $R v$ Caine, 2003 SCC 74, 3 SCR 571 [Malmo-Levine].

23. Stewart, Fundamental Justice, supra note 18 at 151.

24. Stewart, "Bedford and the Structure of Section 7," supra note 9.

25. Canada (Attorney General) v Bedford, 2013 SCC 72 at paras 111-112, 120, 3 SCR 1101 [emphasis in original] [Bedford]. 
unjust still be rationally connected to its purpose or represent a reasonably minimal impairment? And indeed, a majority of the SCC did not use section 1 to uphold a single law that had infringed section 7, regardless of the principle of fundamental justice at stake. ${ }^{26}$ In Bedford, however, the Court attempted to better distinguish the analysis under section 7 from that in section 1 and in the process made it more likely—at least in theory—for "fundamentally unjust" limits on section 7 to be found reasonable. The key shift is that the analysis in section 7 now focuses on the law's impact on the individual rights claimant. ${ }^{27}$ As the Court put it:

All three principles_-arbitrariness, overbreadth, and gross disproportionalitycompare the rights infringement caused by the law with the objective of the law, not with the law's effectiveness. That is, they do not look to how well the law achieves its object, or to how much of the population the law benefits. They do not consider ancillary benefits to the general population. Furthermore, none of the principles measure the percentage of the population that is negatively impacted. The analysis is qualitative, not quantitative. The question under s. 7 is whether anyone's life, liberty or security of the person has been denied by a law that is inherently bad; a grossly disproportionate, overbroad, or arbitrary effect on one person is sufficient to establish a breach of $5.7 .^{28}$

Concerns about the impact and effectiveness of laws at the societal level are thus left to section 1, along with a weighing of collective benefits against the costs to rights holders. Notably, despite this change, the SCC has still not upheld a section 7 infringement as a reasonable limit under section 1, although the Ontario Court of Appeal did so in $R v$ Michand..$^{29}$ Surprisingly, in light of the novel legal issue at stake, the SCC refused Michaud's application for leave to appeal.

For the purposes of this study, the structure of section 7 means that governments can —and routinely do-contest rights claims under section 7 by arguing that any "engagement" with the rights to life, liberty, or the security of person was consistent with the principles of fundamental justice. It is thus crucial to compare how the Attorney General of Canada (AGC) and the SCC dealt with the principles of fundamental justice in section 7 cases, as the issue of the law's reasonableness is effectively decided through the section 7 analysis. That said, the

26. Stewart, Fundamental Justice, supra note 18 at 289.

27. Stewart, "Bedford and the Structure of Section 7," supra note 9.

28. Bedford, supra note 25 at para 123.

29. Rv Michaud, 2015 ONCA 585, 127 OR (3d) 81. See Lilliane Cadieux-Shaw, "A Reluctant Justification: $R v$ Michaud Uses Bedford Approach to Justify Section 7 Infringement" (23 September 2015), online: <thecourt.ca/a-reluctant-justification-r-v-michaud-uses-bedfordapproach-to-justify-section-7-infringement>. 
AGC under Prime Minister Harper always offered a section 1 defence in section 7 cases, both before and after Bedford, suggesting the view that the section 1 analysis is in fact the place to define the law's reasonableness.

\section{METHODOLOGY}

To examine interactions between the Harper government and the SCC over the constitutional reasonableness of criminal justice policies, I focus on the facta (written arguments) submitted by the government of Canada and the published decisions of the SCC. I include both party (appellant or respondent, at the Supreme Court level) and third-party intervener facta submitted by the federal government, since constitutional arguments can appear in either. Moreover, Ottawa's interventions in the criminal justice context often concern what are in fact federal laws, since a defining feature of the Canadian justice system is that, although Criminal Code ${ }^{30}$ offences are created by the federal Parliament, they are usually enforced by provincial Crown prosecutors (in contrast, drug-related offences in Parliament's Controlled Drugs and Substances Act $t^{31}$ are federally-prosecuted). The facta were obtained either freely from the Supreme Court's case information database ${ }^{32}$ or for a nominal fee from the Court's Registrar. The SCC's decisions are from the publicly-available "Supreme Court Judgments" section of Lexum..$^{33}$

To capture the Harper era, the date range used for searches on Lexum was 23 January 2006 - the date of his government's first election-to 1 April 2016, with subsequent analysis of when the government filed its factum in the case. Understandably, there was a lag effect after the party's 2006 election, and all the facta and cases filed in 2006 by the previous government, such as Rodgers, ${ }^{34}$ have been excluded. Conversely, in one case, Safarzadeh-Markhali, ${ }^{35}$ the factum was submitted under Prime Minister Harper but was argued orally and ruled upon under Prime Minister Trudeau; that case was included (notably, the Harper-era factum was not withdrawn and replaced by the new government). For the sake of

30. Criminal Code, RSC 1985, c C-46.

31. Controlled Drugs and Substances Act, SC 1996, c 19.

32. Supreme Court of Canada, "SCC Case Information," online: <www.scc-csc.ca/case-dossier/ info/search-recherche-eng.aspx>.

33. Lexum, "Judgements of the the Supreme Court of Canada," online: <scc-csc.lexum.com/ scc-csc/en/nav.do>.

34. $R v$ Rodgers, 2006 SCC 15, 1 SCR 554.

35. $R v$ Safarzadeh-Markhali, 2016 SCC 14, 1 SCR 180 [Safarzadeh-Markhali]. 
comparison, I included one recent case (Lloyd ${ }^{36}$ ) concerning a law adopted under Prime Minister Harper but that was argued entirely before the SCC under Prime Minister Trudeau.

Within this date range, Government of Canada cases involving the Charter were found in Lexum by conducting an advanced search with the party "Canada," 37 the subject "constitutional law," ${ }^{38}$ and "Charter of Rights" in the full text field. As these parameters miss federal prosecutions that are ambiguously named " $R$. $v$. " (and where the party is simply listed as "Her Majesty the Queen"), I conducted additional full-text searches for "Charter of Rights," "Public Prosecution Service of Canada," and "Attorney General of Canada" respectively, since those terms will appear in the case but not in the formal title. ${ }^{39}$ These searches produced an initial long-list that included several non-Charter cases (see footnote 38). I vetted this list to ensure that the case raised a Charter claim and that the Government of Canada participated in the case, which reduced the number of cases to eighty-eight.

The goal of examining only cases involving discussions of reasonableness in federal criminal justice policy required two additional filters. The first was limiting the list to only those cases that can engage the section 1 "reasonable limits" clause, which, as explained above, means Charter-based challenges to statutes and regulations. The second was selecting only those cases concerning criminal law- the Criminal Code and related amendments—and quasi-criminal law, such as the Controlled Drugs and Substances Act, Youth Criminal Justice Act, Canada Evidence Act, Abolition of Early Parole Act, Proceeds of Crime

36. $R v$ Lloyd, 2016 SCC 13, 1 SCR 130 [Lloyd].

37. The "party" field in Lexum searches both immediate parties to the case and interveners.

38. The search terms for "subject" in Lexum are pre-set, so it was not possible to select the more-specific term "Charter." The consequence was that the search results contained many cases concerned with other constitutional law issues, such as Aboriginal and treaty rights, the federal division of powers, or other provisions of the Constitution Act, 1867. These cases mentioned the Charter, but no rights were claimed or argued. These cases were excluded.

39. The Attorney General of Canada (AGC) is responsible for representing the federal government in civil litigation. See Matthew A Hennigar, "Players and the Process: Charter Litigation and the Federal Government" (2002) 21 Windsor YB Access Just 91; Matthew A Hennigar, "Why Does the Federal Government Appeal to the Supreme Court of Canada in Charter of Rights Cases? A Strategic Explanation" (2007) 41:1 Law \& Soc'y Rev 225. Since 2006, the Public Prosecution Service of Canada (an ostensibly independent unit of the Attorney General of Canada) conducts federal criminal prosecutions. 
(Money Laundering) and Terrorist Financing Act, and any related regulations. ${ }^{40}$ This left twenty cases, and two cases involving identical Charter-based challenges to terrorism offences- $R v$ Khawaja and Sriskandaraja ${ }^{41}$ — that were bundled together as the AGC addressed that issue in a single factum and the SCC ruled on it in Khawaja for both cases. The analysis that follows is therefore effectively based on nineteen cases-eighteen during the Harper era plus the recent Lloyd case mentioned above.

As is well appreciated by those who have attempted it, summary-level analysis of Charter cases raises thorny methodological problems. Aside from the fundamental issue that not all cases are equally salient, in political or jurisprudential terms, cases frequently involve multiple rights claims regarding more than one legislative or regulatory provision. It is thus difficult to know how to "count" each case: Does one focus on claims, challenged provisions, judicial rulings on individual issues, or cases as a whole? My goal in this paper is not to produce a rigorous quantitative analysis so much as to get a more qualitative sense of judicial-executive exchanges about reasonableness; to that end, I approach each case holistically to identify the key issues. For example, in $R v D B,{ }^{42}$ a young offender challenged ten different sections of the Youth Criminal Justice Act under the Charter's section 7 right to life, liberty and security of the person. However, all of these challenges really boiled down to two issues, which are reflected and cross-referenced in those ten sections: Can Parliament create a system of "presumptive offences" for which convicted youths are, unless they can justify otherwise, (1) sentenced as adults, and (2) exempted from the mandatory publication ban on young offenders? In Bedford, ${ }^{43}$ by contrast, the Court addressed three distinct section 7-based challenges to prostitution laws in the Criminal Code: bans on "bawdy-houses," "living off the avails of prostitution," and "communication for the purposes of prostitution" (i.e., street solicitation).

For each case, the Government of Canada's factum was examined to ascertain whether the government conceded the alleged rights infringement and, if not, on what grounds. The same was done for the section 1 reasonable limits test. Governments presented in court with a Charter-based challenge to a statute

40. Criminal Code, supra note 30; Controlled Drugs and Substances Act, supra note 31; Youth Criminal Justice Act, SC 2002, c 1; Canada Evidence Act, RSC 1985, c C-5; Abolition of Early Parole Act, SC 2011, c 11; Proceeds of Crime (Money Laundering) and Terrorist Financing Act, SC 2000, c 17.

41. Rv Khawaja, 2012 SCC 69, 3 SCR 555 [Khawaja]; United States of America v Sriskandarajah, 2012 SCC 70, 3 SCR 609 [Sriskandarajah].

42. $R v D B, 2008$ SCC 25,2 SCR $3[D B]$.

43. Bedford, supra note 25 . 
or regulation have three options: a "full Charter defence," a "limited Charter defence," or "no Charter defence" (i.e., concession). ${ }^{44}$ In a "full Charter defence" the government argues "that the law does not violate the claimant's rights, and, should the court disagree, that the law is a 'reasonable limit' under section 1." ${ }^{45}$ A "limited Charter defence" entails conceding either the rights violation or unreasonableness under section 1, but not both. Notably, the concession could take the form of simply not addressing the issue. A "no Charter defence" entails conceding both the Charter violation and its unreasonableness under section 1 . I coded each case according to where it fit in these categories, and also noted whether the impugned law was adopted under the Harper government.

Next, I reviewed the SCC's decision in the case to determine the following: Did the Court agree with the AGC on the rights infringement, and if not, why? Did the Court agree with the AGC on whether an infringement was a reasonable limit? If the Court found the law unreasonable under section 1 over the AGC's objections, on what grounds (i.e., no pressing and substantial objective, no rational connection, not a minimal impairment, disproportionate effects)? Did the Court accept the AGC's characterization of the law's objective? Was the Court's decision unanimous, or did at least some of the justices agree with the AGC's position?

\section{FINDINGS AND DISCUSSION}

In examining the descriptive information about the nineteen cases summarized in Table 1, some things become readily apparent. The first is that all but one case involved a challenge under section 7 of the Charter, although this was often claimed in conjunction with another right: section $2,8,11,12$, or 15 . The one exception was a section 2(b) freedom of expression challenge to the statutory publication ban on bail hearings (mandatory on request of the accused), raised by several media outlets regarding some of the "Toronto 18 " would-be terrorists. ${ }^{46}$ Second, the AGC conceded only two rights violations, both times freedom of expression (Toronto Star and Bedford). As observed in a previous study, ${ }^{47}$ section 2(b) is the only right the federal government regularly conceded infringing

44. Grant Huscroft, "The Attorney General and Charter Challenges to Legislation: Advocate or Adjudicator?" (1995) 5 NJCL 125; Matthew A Hennigar, "Exploring Complex Judicial-Executive Interaction: Federal Government Concessions in Charter of Rights Cases" (2010) 43:4 Can J Pol Sci 821 at 826 [Hennigar, "Exploring Complex Judicial-Executive Interaction"].

45. Ibid.

46. Toronto Star Newspapers Ltd v Canada, 2010 SCC 21, 1 SCR 721 [Toronto].

47. Hennigar, "Exploring Complex Judicial-Executive Interaction," supra note 44 at 833-35. 
between 1982 and 2004, and these concessions were driven by the SCC's long-standing and expansive definition of "expression" as anything that conveys meaning non-violently. The jurisprudence has made it almost impossible for governments to challenge alleged infringements of freedom of expression under anything but the section 1 reasonable limits test, so the concessions here are not surprising. Moreover, in the case of Bedford, the freedom of expression violation (a ban on "communicating for the purposes of prostitution" in section 213(1)(c) of the Criminal Code) was already well-established by the SCC's precedent on the identical claim and provision in the Prostitution Reference. ${ }^{48}$ Third, the AGC never explicitly conceded that a rights infringement was unreasonable under section 1 , and in only one case $(A h m a d)^{49}$ did the government implicitly concede by failing to provide a section 1 defence.

Notably, the government's consistently defensive posture means that it does not appear to matter whether impugned laws were adopted by a previous government of a different party. Of the nineteen statutes and regulations challenged, fourteen ( 74 per cent) were adopted by a previous government. This pattern continued with the Trudeau government's defence of the controversial mandatory minimum sentences for drug possession and trafficking, adopted under Stephen Harper in the Safe Streets and Communities Act. ${ }^{50}$ Overt concessions by the federal government in Charter cases have always been relatively rare, but "limited Charter defences" were not, even if they usually took the form of conceding a section 2(b) violation or an implicit concession of section 1 by offering no section 1 defence. Between 1982 and 2004 the federal government conceded the rights violation but not section 1 in 15 of 139 challenges (11 per cent), and the reverse, twenty-one times (15 per cent). ${ }^{51}$ With respect to just Criminal Code cases in that period, a limited defence was offered sixteen times ( 22.5 per cent). ${ }^{52}$ As shown in Table 2, limited defences-again, on section 2(b), and one case where section 1 was not addressed-represented the federal government's strategy in 17 per cent of the Charter challenges in this study. In that sense, there is some continuity with the AGC's past practice.

48. Reference re ss 193 and 195.1(1)(c) of the Criminal Code (Man), [1990] 1 SCR 1123, 77 CR (3d) 1 [Prostitution Reference].

49. Rv Ahmad, 2011 SCC 6, 1 SCR 110 [Ahmad]. And ultimately this concession was irrelevant, as the Court agreed with the AGC that there was no rights infringement.

50. Safe Streets and Communities Act, SC 2012, c 1.

51. Hennigar, "Exploring Complex Judicial-Executive Interaction," supra note 44 at 832.

52. Ibid at 834 . 
TABLE 1: SUMMARY OF SCC CASES INVOLVING CHARTER CHALLENGES TO CRIMINAL LAWS, 2006-2016

\begin{tabular}{|c|c|c|c|c|c|c|c|}
\hline Case & Year & $\begin{array}{l}\text { Charter } \\
\text { Sections }\end{array}$ & $\begin{array}{l}\text { AGC } \\
\text { Party }\end{array}$ & $\begin{array}{c}\text { AGC } \\
\text { Concede } \\
\text { Violation }\end{array}$ & $\begin{array}{c}\text { AGC } \\
\text { Concede } \\
\text { S. } 1\end{array}$ & $\begin{array}{c}\text { AGC-SCC } \\
\text { Agree on } \\
\text { Right? }\end{array}$ & $\begin{array}{c}\text { AGC-SCC } \\
\text { Agree on } \\
\text { S.1? }\end{array}$ \\
\hline$R v D B$ & 2008 & 1,7 & Int & No & No & No & No \\
\hline$R v J Z S$ & 2010 & $\begin{array}{l}1,7 \\
11(\mathrm{~d})\end{array}$ & Int & No & No & Yes & $\mathrm{n} / \mathrm{a}$ \\
\hline $\begin{array}{l}\text { Toronto Star } \\
\text { Newspapers } \\
\text { Ltd v Canada } \\
{[w / C B C v \text { The }} \\
\text { Queen }]^{*}\end{array}$ & 2010 & $1,2(b)$ & $\begin{array}{c}\text { Res/Int } \\
\text { (AGC/ } \\
\mathrm{DPP})\end{array}$ & Yes & No & Yes & Yes \\
\hline $\begin{array}{l}\text { Canada } \\
\text { (AG) v PHS } \\
\text { Community } \\
\text { Services Society } \\
\text { ("Insite") }\end{array}$ & 2011 & $\begin{array}{c}1,7 \\
24(1)\end{array}$ & $\begin{array}{l}\text { App/ } \\
\text { Res }\end{array}$ & No & No & Yes & $\mathrm{n} / \mathrm{a}$ \\
\hline$R v A h m a d$ & 2011 & 7 & App & No & $\mathrm{n} / \mathrm{a}$ & Yes & $\mathrm{n} / \mathrm{a}$ \\
\hline $\begin{array}{l}R v \text { Khawajal } \\
\text { Sriskandarajah } \\
v \text { USA }\end{array}$ & 2012 & $1,2,7$ & Res & No & No & Yes & $\mathrm{n} / \mathrm{a}$ \\
\hline$R v T_{s e}$ & 2012 & $\begin{array}{c}1,7,8 \\
11(d)\end{array}$ & Int & No & No & No & No \\
\hline $\begin{array}{l}R v \text { St-Onge } \\
\text { Lamoureux }\end{array}$ & 2012 & $\begin{array}{l}1,7, \\
11(\mathrm{c}), \\
\text { (d) }\end{array}$ & Int & No & No & No & $\mathrm{No}^{\dagger}$ \\
\hline $\begin{array}{l}\text { Canada }(A G) v \\
\text { Bedford }\end{array}$ & 2013 & $1,2(b), 7$ & $\begin{array}{c}\text { App/ } \\
\text { Res }\end{array}$ & $\begin{array}{c}\mathrm{N}(\mathrm{s} .7) \\
\mathrm{Y}(\mathrm{s} .2(\mathrm{~b}))\end{array}$ & $\mathrm{No} / \mathrm{No}$ & No $(s .7)^{\dagger}$ & No (s.7) \\
\hline$R v$ Levkovic & 2013 & 1,7 & Int & No & No & Yes & $\mathrm{n} / \mathrm{a}$ \\
\hline $\begin{array}{l}\text { Canada }(A G) v \\
\text { Whaling }\end{array}$ & 2014 & $\begin{array}{l}1,7 \\
11(\mathrm{~h})\end{array}$ & App & No & No & No & No \\
\hline$R v$ Conception & 2014 & 1,7 & Int & No & No & Yes & $\mathrm{n} / \mathrm{a}$ \\
\hline $\begin{array}{l}\text { Wakeling } v \\
\text { USA }\end{array}$ & 2014 & $1,7,8$ & Res & No & No & Yes & $\mathrm{n} / \mathrm{a}$ \\
\hline $\begin{array}{l}R v N u r[R v \\
\text { Charles }]\end{array}$ & 2015 & 1,12 & App & No & No & No & No \\
\hline$R v$ Smith & 2015 & 1,7 & App & No & No & No & No \\
\hline $\begin{array}{l}\text { Carter v } \\
\text { Canada }\end{array}$ & 2015 & $1,7,15$ & Res & No & No & No & No \\
\hline
\end{tabular}




\begin{tabular}{|c|c|c|c|c|c|c|c|}
\hline Case & Year & $\begin{array}{l}\text { Charter } \\
\text { Sections }\end{array}$ & $\begin{array}{l}\text { AGC } \\
\text { Party }\end{array}$ & $\begin{array}{c}\text { AGC } \\
\text { Concede } \\
\text { Violation }\end{array}$ & $\begin{array}{c}\text { AGC } \\
\text { Concede } \\
\text { S. } 1\end{array}$ & $\begin{array}{l}\text { AGC-SCC } \\
\text { Agree on } \\
\text { Right? }\end{array}$ & $\begin{array}{c}\text { AGC-SCC } \\
\text { Agree on } \\
\text { S.1? }\end{array}$ \\
\hline $\begin{array}{l}\text { Canada }(A G) \\
v \text { Federation of } \\
\text { Law Societies }\end{array}$ & 2015 & $1,7,8$ & App & No & No & No & No \\
\hline $\begin{array}{l}R v \text { Safarzadeh- } \\
\text { Markhali }\end{array}$ & 2016 & 1,7 & Int & No & No & No & No \\
\hline$R v$ Lloyd $^{\$}$ & 2016 & $1,7,12$ & Res & No & No & No & No \\
\hline
\end{tabular}

* The SCC combined the two cases in a single decision. The AGC appeared in one as the respondent, and the Director of Public Prosecutions Canada (DPP) appeared as intervener in the other, but they filed a joint factum for the two cases. As such, they are combined for the purposes of this analysis.

$+\quad$ SCC upheld law under section 1 only after severing two provisions, implying that those were not reasonable limits.

‡ The section 2(b) claim in Bedford was addressed by the AGC, but not the SCC, which resolved the case on section 7 grounds.

$\S \quad$ Factum and oral argument under PM Trudeau.

\section{TABLE 2: AG CANADA LITIGATION STRATEGIES IN CASES CHALLENGING FEDERAL CRIMINAL LAWS}

\begin{tabular}{ccccccc} 
Charter & \multicolumn{5}{c}{ AG Canada Party } \\
Defense & Appellant & Respondent & X-Appeals & Party Total & Intervener & Total \\
Full & 4 & 4 & 2 & 10 & 9 & 19 \\
column $\%$ & $80.0 \%$ & $80.0 \%$ & $66.6 \%$ & $76.9 \%$ & $90.0 \%$ & $82.6 \%$ \\
Limited & 1 & 1 & 1 & 3 & 1 & 4 \\
column $\%$ & $20.0 \%$ & $20.0 \%$ & $33.3 \%$ & $23.1 \%$ & $10.0 \%$ & $17.4 \%$ \\
None & 0 & 0 & 0 & 0 & 0 & 0 \\
Total & 5 & 5 & 3 & 13 & 10 & 23 \\
row $\%$ & $21.7 \%$ & $21.7 \%$ & $13.0 \%$ & $56.5 \%$ & $43.5 \%$ & $100 \%$ \\
\hline
\end{tabular}

NOTE: Total cases exceed nineteen because of cases where more than one issue in the statute or regulation was challenged (ex: Bedford, DB, JZS), and Toronto Star where the government of Canada appeared as both a party and intervener. 
Using the more holistic approach to coding Charter challenges noted above, there were twenty-three statutory or regulatory issues addressed in this study. The SCC invalidated fourteen of them, ${ }^{53}$ for a government success rate of only 39 per cent. This is a significant drop from the 1982-2003 rate of 65 per cent for all federal statutes challenged under the Charter, ${ }^{54}$ although differences in coding schemes frustrate direct comparisons. Some of these invalidations were well-publicized, such as the ban on physician-assisted death in Carter, ${ }^{55}$ the three prostitution provisions in Bedford, the presumptive adult sentences and removal of publication bans for some young offenders in $D B$, mandatory minimum sentences in $\mathrm{Nur}^{56}$ and Lloyd, the denial of enhanced credit for pre-sentence custody to offenders who were denied bail because of a prior conviction in Safarzadeh-Markhali, and the ban on "medicinal" marijuana in non-dried forms in Smith. ${ }^{57}$ Other policy losses included Prime Minister Harper's attempt to abolish early parole provisions retroactively in Whaling, ${ }^{58}$ restricting the evidence an accused can use to challenge breathalyzer evidence in St-Onge Lamoureux, ${ }^{59}$ the decision not to require notification to persons when their private communications have been intercepted by authorities without a warrant in $T s e,{ }^{60}$ and the application to legal firms of Canada's financial reporting rules that are designed to combat terrorism financing and money laundering by organized crime in Federation of Law Societies. ${ }^{61}$

In contrast, the Court upheld the constitutionality of several terrorism-related laws, including two anti-terrorism provisions of the Criminal Code (the "motive clause" and "participating in or contributing to the activity of a terrorist group" in Khawaja/Sriskandarajah), and giving the Federal Court jurisdiction over disclosure of evidence pertaining to international relations, national defence or national security in Ahmad. ${ }^{62}$ The Court also upheld the publication bans on bail hearings at the request of the accused in Toronto Star, which was raised in the context of a high-profile terrorism case; the Criminal Code's requirement of

53. For the list of cases, see Table 3.

54. Kelly, Governing with the Charter, supra note 15 at 148.

55. Carter v Canada, 2015 SCC 5, 1 SCR 331 [Carter].

56. Rv Nur, 2015 SCC 15, 1 SCR 773 [Nur].

57. Rv Smith, 2015 SCC 34, 2 SCR 602 [Smith 2015].

58. Canada (Attorney General) $v$ Whaling, 2014 SCC 20, 1 SCR 392 [Whaling].

59. Rv St-Onge Lamoureux, 2012 SCC 57, 3 SCR 187 [St-Onge Lamoureux].

60. $R v$ Tse, 2012 SCC 16, 1 SCR 531.

61. Canada (Attorney General) v Federation of Law Societies, 2015 SCC 7, 1 SCR 401 [Federation of Law Societies].

62. Ahmad, supra note 49. 
hospital consent to provide treatment when a judge finds an accused unfit to stand trial because of mental illness; ${ }^{63}$ the Criminal Code's provision allowing Canadian law enforcement officials to disclose to a foreign state, without the consent of the surveilled, intercepted private communications; ${ }^{64}$ the Criminal Code provision permitting privacy screens for youth who testify and the presumption in the Canada Evidence Act that youth under the age of fourteen are competent to testify and can "promise to tell the truth" rather than "swear an oath"; ${ }^{65}$ and the Criminal Code prohibition on disposing of the dead body of child with intent to conceal its delivery. ${ }^{66}$ The Controlled Drugs and Substances Act was technically upheld in the high-profile "Insite" $\mathrm{case}^{67}$ (in keeping with established precedent in $R v$ Malmo Levine; $R v$ Caine $\left.^{68}\right)$, but the federal Minister of Justice got a firm dressing-down by the Court about how he exercised his discretion (authorized by section 56 of the CDSA) regarding whether to exempt the Vancouver safe-injection site from the law. Despite evidence Insite was improving the health of the addict community, the Minister tried to end the site's exemption. The Court, however, disagreed and essentially removed his discretion by ordering him to grant the exemption. It should also be noted that the Court only upheld the CDSA here because of the availability of the ministerial exemption under section 56 for those who need it; the Court's finding implies that such exemptions must be given to safe-injection clinics when they have proven their effectiveness. And it is a small step to argue that safe-injection sites are constitutionally required (a step the Court refrained from taking, however). Thus, although Insite was an important judicial repudiation of the Harper government's approach to illicit drugs, it is technically coded as a 'win' on the statutory challenge.

Following a pattern observed previously, the government's chance of success drops precipitously once section 1 has been engaged. That is, once the Court has decided that a law infringes a right, the judges are "less willing to give the government the benefit of the doubt under s. 1"-less than 20 per cent of the time between 1994 and 2003. ${ }^{69}$ In this period, the Court upheld a law under section 1 only once (the publication ban in Toronto Star) and found

63. $R v$ Conception, 2014 SCC 60, 3 SCR 82 [Conception].

64. Wakeling $v$ United States of America, 2014 SCC 72, 3 SCR 549 [Wakeling].

65. $R v$ JZS, 2010 SCC 1,1 SCR 3.

66. $R v$ Levkovic, 2013 SCC 25, 2 SCR 204 [Levkovic].

67. Canada (Attorney General) v PHS Community Services Society, 2011 SCC 44, 3 SCR 134 [Insite].

68. Malmo-Levine, supra note 22.

69. Daved Muttart, The Empirical Gap in Jurisprudence: A Comprehensive Study of the Supreme Court of Canada (Toronto: University of Toronto Press, 2007) at 161-62. 
infringements unreasonable fourteen times, for a government success rate of only 6.7 per cent. ${ }^{70}$ The conclusions from studies of earlier periods-that the Court finds rights infringements much more often than it finds such infringements unreasonable $^{71}$ - does not appear to hold true here. As discussed below, this is likely a product of the rights being infringed-mostly sections 7, 8 and 12-that contain internal limits similar to section 1 , and so it is difficult to justify their limitation as "reasonable" subsequently under the Oakes test.

So, whose laws are being invalidated in these cases? If we just count the eleven cases in which a federal law was invalidated (rather than counting multiple provisions of the same law), six of them struck down laws adopted by the Harper government: St-Onge Lamoureux, Whaling, Smith, Nur, Lloyd, and Safarzadeh-Markali. In the other five-including the high-profile DB, Bedford, and Carter losses - the laws were adopted by previous governments, in some cases decades earlier. Manfredi's recent study found that only one-quarter of the laws struck down by the SCC during the Harper era were passed by that government, leading him to dismiss the popular narrative that Harper's relationship with the Court was especially hostile. ${ }^{72}$ My findings for Harper's criminal laws are significantly higher (55 per cent), and include two rejections of mandatory minimum sentencing laws. As such, it is safe to say that the Court was hostile to the signature component of the Harper government's "law and order" policy agenda. Moreover, while it is noteworthy that some of the Conservatives' highest-profile criminal policy losses concerned pre-Harper laws, it should be stressed that his government strongly supported these laws (and defended them in court). This is particularly the case in $R v D B$, regarding the Liberals' 2002 Youth Criminal Justice Act, whose more-punitive provisions regarding repeat and serious violent offenders were in no small measure the result of exceptionally hard lobbying by the Reform Party and Canadian Alliance, the precursors to

70. In St-Onge Lamoureux, the Court technically upheld one of the statutory restrictions on evidence that could be used to challenge breathalyzer evidence, but severed two others for failing the Oakes test; I counted this as a "failure" for the government. Supra note 59 at paras 64-67.

71. Hiebert, Limiting Rights, supra note 14; Kelly, Governing with the Charter, supra note 15.

72. Christopher P Manfredi, "Conservatives, the Supreme Court of Canada, and the Constitution: Judicial-Government Relations, 2006-2015” (2015) 52:3 Osgoode Hall LJ 951. 
Harper's Conservatives. ${ }^{73}$ As well, following Bedford, the Conservatives moved quickly to restrict communications for the purposes of prostitution and to re-ban pimps and others living off the avails of prostitution exploitatively, within the new framework of criminalizing the buying of sex. ${ }^{74}$

I turn now to a more detailed examination of the AGC and SCC's respective arguments on rights and section 1 .

\section{A. SCC-AGC EXCHANGES WHERE DISAGREEMENT ABOUT RIGHTS INFRINGEMENTS}

As we already know that the AGC did not concede that any of its impugned laws violated sections 8,7 or 12 , we can conclude that in none of the cases studied here did the government feel its laws were unreasonable, arbitrary, overbroad, grossly disproportional, or otherwise inconsistent with a principle of fundamental justice. However, as Table 3 illustrates, the Court disagreed with the AGC roughly a dozen times about the prima facie rights infringement. As is often the case, the Court declined to answer some rights claims when it was able to resolve it on the basis of another right, especially if the latter was narrower in focus. For example, the Court ignored the section 15 equality rights claim based on disability in Carter, and the freedom of expression challenge to the solicitation ban in Bedford, on the grounds that the section 7 claim in each was successful.

Without engaging in detailed descriptions of each of these cases, some findings merit further discussion. The first, and perhaps most important, is that the Court sometimes rejected the AGC's characterization of the law's objective. This is a crucial, and, as far as I can ascertain, novel line of systematic inquiry using the government's facta as the baseline for comparison. One cannot assess whether the policy instrument used by a government was disproportionate, arbitrary, or overbroad without reference to the policy's objective. As such, the characterization of the objective drives all subsequent analysis. One might expect the Court to defer to the government's account of what its laws are for,

73. See Tim Heinmiller, Matthew Hennigar \& Sandra Kopec, "Degenerative Politics and Youth Criminal Justice Policy in Canada" (Paper delivered at the annual conference of the Canadian Political Science Association, Calgary, 31 May 2016) [unpublished]. The findings help explain the perception that Harper was on a "losing streak" in the SCC: He was, at least in cases dealing with criminal justice laws. In 2015 the Conservatives lost four straight cases, and two more Harper-era policies were struck down shortly after the 2015 election. Moreover, holding the relatively obscure victories in Conception and Wakeling aside, the government had not won a major criminal law case outright since Levkovic in 2013.

74. Protection of Communities and Exploited Persons Act, SC 2014, c 25. 
but, as Table 3 reveals, that was not the case in three high-profile losses: Smith, Carter, and Bedford.

$S_{\text {Smith }}{ }^{75}$ involved a challenge to the federal government's regulatory regime that only permitted dried marijuana for medicinal use; the challenge was brought not by a user, but an individual who wished to sell products containing other cannabis plant derivatives-such as hashish and THC-and synthetic cannabinoids. The AGC's factum emphasizes that there is no medical or clinical evidence supporting the therapeutic use of marijuana, and that the government has only allowed dried cannabis as a result of the Ontario Court of Appeal ruling in Parker $^{76}$ that a blanket ban on marijuana with no exceptions for medicinal use is constitutionally invalid. Part of the government's response to this ruling was to create a network of suppliers authorized by Health Canada. No such system exists for non-dried forms, however, and the government has the legal authority to restrict access to controlled substances. As such, the AGC argued that the state's objective in excluding non-dried forms was "protecting health and safety by ensuring that other drugs put forward for therapeutic purposes comply with applicable safety, quality, and efficacy requirements." ${ }^{\prime 7}$ The lower courts rejected this argument as a "red herring," and the SCC followed suit, observing that the regulations do not actually subject dried marijuana to these requirements. ${ }^{78}$ Moreover, the Court accepted the trial court's finding that "in some circumstances the use of cannabis derivatives is more effective and less dangerous than smoking or otherwise inhaling dried marihuana." ${ }^{\prime 9}$ The Court reframed the legislative objective more narrowly as "the protection of health and safety," and then found the regulations arbitrarily infringed the section 7 rights to liberty and security of the person since there was no medical rationale for regulating the drug's form; the regulations also failed the rational connection component of the Oakes test.

75. Smith 2015, supra note 57.

76. $R v$ Parker, (2000) 49 OR (3d) 481, 188 DLR (4th) 385 (ONCA).

77. Smith 2015, supra note 57 (Factum of the Appellant at para 107).

78. Smith 2015, supra note 57 at para 24.

79. Ibid at para 19 . 


\begin{tabular}{|c|c|c|c|}
\hline Case & $\begin{array}{c}\text { Rights } \\
\text { Infringed }\end{array}$ & $\begin{array}{c}\text { Principles of } \\
\text { Fundamental Justice } \\
\text { Problem }\end{array}$ & $\begin{array}{l}\text { SCC Accept AGC's } \\
\text { Description of Law's } \\
\text { Objective? }\end{array}$ \\
\hline $\begin{array}{l}R \vee D B: \text { adult } \\
\text { sentences }\end{array}$ & 7 (liberty) & $\begin{array}{l}\text { no presumption of } \\
\text { diminished moral } \\
\text { culpability for youth } \\
\text { [new]; reverse onus }\end{array}$ & Yes \\
\hline $\begin{array}{l}R v D B: \text { no } \\
\text { publication ban }\end{array}$ & 7 (liberty) & $\begin{array}{l}\text { no presumption of } \\
\text { diminished moral } \\
\text { culpability for youth } \\
\text { [new]; reverse onus }\end{array}$ & Yes \\
\hline$R v$ Tse & $\begin{array}{c}8 \text { (unreasonable } \\
\text { search \& seizure) }\end{array}$ & $\mathrm{n} / \mathrm{a}$ & Yes \\
\hline $\begin{array}{l}R v \text { St-Onge } \\
\text { Lamoureux }\end{array}$ & $\begin{array}{c}11(\mathrm{~d}) \\
\text { (presumption of } \\
\text { innocence) }\end{array}$ & $\mathrm{n} / \mathrm{a}$ & Yes \\
\hline $\begin{array}{l}\text { Can v Bedford: } \\
\text { bawdy-house }\end{array}$ & $\begin{array}{l}7 \text { (security of } \\
\text { person) }\end{array}$ & grossly disproportional & No \\
\hline $\begin{array}{l}\text { Can } v \text { Bedford: living } \\
\text { off avails }\end{array}$ & $\begin{array}{l}7 \text { (security of } \\
\text { person) }\end{array}$ & overbroad & No \\
\hline $\begin{array}{l}\text { Can v Bedford: } \\
\text { solicitation }\end{array}$ & $\begin{array}{l}7 \text { (security of } \\
\text { person) }\end{array}$ & grossly disproportional & No \\
\hline Carter $v$ Canada & $\begin{array}{l}7 \text { (life, lib., s. } \\
\text { of p.) }\end{array}$ & overbroad & No \\
\hline $\begin{array}{l}\text { Canada v Fed of Law } \\
\text { Societies }\end{array}$ & $\begin{array}{c}7 \text { (liberty) } \\
8 \text { (unreasonable } \\
\text { search \& seizure) }\end{array}$ & $\begin{array}{l}\text { undermines lawyer's duty } \\
\text { of commitment to the } \\
\text { client's cause [new]; n/a }\end{array}$ & Yes \\
\hline$R v$ Smith & 7 (liberty, s. of p.) & arbitrary & No \\
\hline $\begin{array}{l}R v \\
\text { Safarzadeh-Markhali }\end{array}$ & 7 (liberty) & overbroad & Yes \\
\hline $\begin{array}{l}\text { Canada }(A G) v \\
\text { Whaling }\end{array}$ & $\begin{array}{l}\text { 11(h) (double } \\
\text { jeopardy) }\end{array}$ & $\mathrm{n} / \mathrm{a}$ & Yes \\
\hline$R v N u r$ & $\begin{array}{c}12 \text { (cruel } \\
\& \text { unusual } \\
\text { punishment) }\end{array}$ & $\mathrm{n} / \mathrm{a}$ & Yes \\
\hline$R v$ Lloyd & $\begin{array}{c}12 \text { (cruel } \\
\& \text { unusual } \\
\text { punishment) }\end{array}$ & $\mathrm{n} / \mathrm{a}$ & Yes \\
\hline
\end{tabular}


In Carter, the Court rejected the AGC's position that the objective of the ban on physician-assisted death in sections 14 and 241(b) of the Criminal Code is the "preservation of life and the protection of vulnerable people-the poor, the elderly, people with disabilities." ${ }^{80}$ The AGC cited the Court's 1993 Rodriguez ${ }^{81}$ ruling on the same issue in support of this characterization, but the justices in Carter disagreed with that interpretation. Despite repeated statements by the majority in Rodriguez that the "preservation of life" was one of the law's objectives, the Court in Carter drew a distinction between the broader "animating social value" of protecting life and more specific legislative objectives. In this case, the Court found the latter to be "the narrow goal of preventing vulnerable persons from being induced to commit suicide at a time of weakness." ${ }^{\prime 2}$ The Court concluded that this narrower goal could not justify denying assisted death to consenting, mentally-competent adults who have "a grievous and irremediable medical condition (including an illness, disease or disability) that causes enduring suffering that is intolerable to the individual." 83 The ban was thus found to violate the rights to life, liberty, and security of the person of such individuals in an overbroad manner, and for the same reason failed the "minimal impairment" test under section 1.

The Court's treatment of the legislative objectives in Bedford is the most striking. The government's position was that although the bans on bawdy-houses and street solicitation were to prevent "serious social nuisance related problems," and on "living off the avails" to prevent exploitation, the three provisions "constitute an interconnected whole, demonstrating Parliament's intent is to deter the business of prostitution." ${ }^{84}$ The SCC, however, rejected this overarching legislative intent and treated each ban in isolation, since they had not been drafted as part of a coherent legislative package (notably in contrast to the new regime adopted by the Conservatives in 2014). With respect to bawdy-houses and solicitation, the Court found that the objective was "to prevent community harms in the nature of nuisance"; ${ }^{85}$ citing the 1990 Prostitution Reference that upheld

80. Carter, supra note 55 (Factum of the Respondent at para 4).

81. Rodriguez v British Columbia (Attorney General), [1993] 3 SCR 519, 107 DLR (4th) 342 [Rodriguez].

82. Carter, supra note 55 at para 78.

83. Ibid at para 4 .

84. Bedford, supra note 25 (Factum of the Appellant at para 88). Notably, the government argued that part of the reason to deter prostitution was its inherently unsafe nature, and that there was not enough evidence that the bans increased the risks to prostitutes to find a violation of security of person (though it did concede that "liberty" was engaged).

85. Bedford, supra note 25 at para 131. 
the ban on solicitation, the justices noted such concerns as "street congestion and noise, oral harassment of non-participants and general detrimental effects on passers-by or bystanders, especially children." ${ }^{86}$ The Court found the purpose of the ban on "living off the avails" was to combat the "parasitic, exploitative conduct" of pimps. ${ }^{87}$ Curiously, the Court appears to have disregarded the fact that the AGC also recognized these more precise legislative objectives for each ban. Even stranger, the justices claimed that the AGC argued that the "true objective of [the anti-pimping provision] is to target the commercialization of prostitution, and to promote the values of dignity and equality," ${ }^{\prime 8}$ an objective the Court then sharply rejects. However, in neither of its two facta (one as appellant, another as respondent on a cross-appeal) does the AGC mention "dignity" or "equality," focusing instead on "deterring prostitution and its commercialization" and combatting exploitation. The Court's apparent misreading of the government's position aside, the rejection of "deterring prostitution" as a broader legislative objective had the important consequence of facilitating the SCC's conclusion that the bans on solicitation and bawdy-houses were "grossly disproportional" under section 7's principles of fundamental justice, and had a disproportionately negative effect under section 1 . The Court found the negative effects on the security and health of sex workers vastly outweighed the benefits of "preventing nuisances," but the calculus would arguably be altered if the benefits of "deterring prostitution" were added to the equation.

A second interesting finding at this stage of analysis is that the Court sometimes had to rely on discovering a new principle of fundamental justice to conclude that a law violated section 7 . One principle came as an apparent surprise to the AGC, in Federation of Law Societies. In that case, the AGC argued that although forcing law firms to comply with financial reporting regulations designed to catch money laundering and terrorist financing engages the lawyers' (but not the clients') liberty interests, it did not offend any principles of fundamental justice in the process. In particular, the AGC observed that "the independence of the Bar" was not a principle of fundamental justice, and that although "solicitor-client privilege" is, it only applies where the client's section 7 rights are infringed - which was not the case here. The SCC majority agreed on both points, but then crafted a new principle: That a lawyer has a "duty of commitment to the client's cause," that was offended by the financial reporting regime, which required lawyers to keep detailed records on their clients' identities

86. Ibid at para 146 .

87. Ibid at para 137.

88. Ibid at para 138. 
and transactions, and to submit their offices to warrantless searches by government agents. ${ }^{89}$ In $R v D B$, regarding the presumptive offences provisions of the Youth Criminal Justice Act, the Court's narrow majority ruled for the first time that young people are entitled to a presumption of diminished moral culpability as a principle of fundamental justice, while also finding a violation of the established principle against reverse onus. Both of these findings were made over the strenuous objection of the AGC. As well, the four dissenting justices on the Court took a somewhat different position on the principles of fundamental justice. While the minority justices agreed that the reduced moral blameworthiness of young persons is a principle, they pointed to the many special protections in the YCJA for accused and convicted youths as evidence of respect for that principle, and rejected the majority's conclusion that the principle entailed a presumption of lower youth sentences. Similarly, while agreeing that reverse onus provisions are typically unconstitutional, the minority found no such problem with the Act: The Crown still bears the "burden of proving aggravating sentencing factors beyond a reasonable doubt," because the onus remains on the Crown to prove the youth guilty of the presumptive offence beyond a reasonable doubt. ${ }^{90}$

\section{B. SCC-AGC EXCHANGES WHERE DISAGREEMENT ABOUT SECTION 1}

As discussed earlier, it is virtually impossible for a government to argue successfully that a law that infringes sections 7,8 , or 12 is reasonable under section 1 , although it remains to be seen whether the revised "principles of justice" standards articulated in Bedford will prove otherwise. Indeed, in the pre-Harper period, the AGC sometimes offered no section 1 argument in section 7 cases, with the explanation that such a defence was simply impossible given the jurisprudence. ${ }^{91}$ As Stewart notes, however, the Court had never ruled out the possibility that section 7 infringements could be reasonable under section 1, and even before Bedford had tried to articulate a distinction between the analysis required for each. ${ }^{92}$ It is interesting, therefore, that the AGC invoked that distinction in every case after 2006 involving a section 7 challenge to criminal law, conceding nothing under section 1. However, it was to little apparent effect: In no case where the Court found a section 7 infringement did the justices accept that it was reasonable under section 1. Ironically, in Bedford the Court dismissively

89. Federation of Law Societies, supra note 61 at para 8.

90. DB, supra note 42 at para 139 .

91. Hennigar, "Exploring Complex Judicial-Executive Interaction," supra note 44 at 833.

92. Stewart, Fundamental Justice, supra note 18 at 289-90. 
concluded, "[t]he appellant Attorneys General have not seriously argued that the laws, if found to infringe s. 7, can be justified under s. 1 of the Charter. Only the Attorney General of Canada addressed this in his factum, and then, only briefly." ${ }^{93}$ In fact, the two facta filed by the AGC (above) each contained a concise but complete section 1 defence.

\begin{tabular}{|c|c|c|c|c|}
\hline Case & $\begin{array}{l}\text { Pressing \& } \\
\text { Substantial } \\
\text { Objective? }\end{array}$ & $\begin{array}{l}\text { Rational } \\
\text { Connect? }\end{array}$ & $\begin{array}{c}\text { Minimal } \\
\text { Impairment? }\end{array}$ & $\begin{array}{c}\text { Proportionate } \\
\text { Effects? }\end{array}$ \\
\hline$R v D B$ : adult sentences & Yes & No & No & $\mathrm{n} / \mathrm{a}$ \\
\hline$R v D B$ : no publication ban & Yes & No & No & $\mathrm{n} / \mathrm{a}$ \\
\hline$R v T_{s e}$ & Yes & Yes & No & $\mathrm{n} / \mathrm{a}$ \\
\hline$R v$ St-Onge Lamoureux & Yes & No & No & $\mathrm{n} / \mathrm{a}$ \\
\hline $\begin{array}{l}\text { Can v Bedford: } \\
\text { bawdy-house }\end{array}$ & Yes & Yes(?) & No & No \\
\hline $\begin{array}{l}\text { Can } v \text { Bedford: living off } \\
\text { avails }\end{array}$ & Yes & Yes(?) & No & No \\
\hline $\begin{array}{l}\text { Can v Bedford: } \\
\text { solicitation }\end{array}$ & Yes & Yes(?) & No & No \\
\hline Carter v Canada & Yes & Yes & No & $\mathrm{n} / \mathrm{a}$ \\
\hline $\begin{array}{l}\text { Canada v Fed of Law } \\
\text { Societies }\end{array}$ & Yes & Yes & No & $\mathrm{n} / \mathrm{a}$ \\
\hline$R v$ Smith & Yes & No & $\mathrm{n} / \mathrm{a}$ & $\mathrm{n} / \mathrm{a}$ \\
\hline$R v$ Safarzadeh-Markhali & Yes & Yes & No & No \\
\hline Canada $(A G) v$ Whaling & Yes & Yes & No & No \\
\hline$R v N u r$ & Yes & Yes & No & No \\
\hline$R v$ Lloyd & Yes & Yes & No & No \\
\hline TOTALS & Yes $=14$ & $\begin{array}{l}\mathrm{Y}=10 \\
\mathrm{~N}=4\end{array}$ & $\begin{array}{c}\text { Yes }=0 \\
\mathrm{No}=13 \\
\mathrm{n} / \mathrm{a}=1\end{array}$ & $\begin{array}{l}\mathrm{Yes}=0 \\
\mathrm{No}=7 \\
\mathrm{n} / \mathrm{a}=7\end{array}$ \\
\hline
\end{tabular}

Table 4 summarizes the Court's decisions on each component of the section 1 "reasonable limits" test in cases where the law was invalidated over the

93. Bedford, supra note 25 at para 161. 
objection of the AGC (bearing in mind that the government never conceded unreasonableness under section 1). Note that the Court never concludes that the law lacks a pressing and substantial objective, which is consistent with the common observation that the Court usually defers to governments at this stage. However, if we recall the far right column in Table 3, this deference is called into question: Holistically speaking, in 36 per cent (5/14) of the provisions listed here, the Court only upholds the legislative objective after rejecting the AGC's characterization of it. In those cases, the Court is reframing the law's objective and then upholding it as pressing and substantial—but then turning around and finding that the means used to achieve it were irrational, overbroad, or disproportionate.

As expected from previous studies, ${ }^{94}$ most laws were found unreasonable for failing the "minimal impairment" analysis: All but one of the fourteen in this study. In the one exception (Smith), the law was found to have no rational connection to the legislative objective, which is hardly surprising since it was also found to be arbitrary under section 7. An unfavourable Court ruling under rational connection is as profound a rejection of the government's policy as we typically see under section 1 , as it essentially tells the government that its law makes no sense. In addition to Smith, the Court's majority took this position in $D B$ and St-Onge Lamoureux, while also finding that the section 7 violation was not a minimal impairment in both cases. Although I coded Bedford as a "win" under rational connection, the Court's cursory treatment of section 1 did not explicitly mention that issue; nonetheless, the justices made the effort to identify quickly that the legislative provisions were not minimal impairments and had disproportionate effects, but did not flag irrationality, and the Court appeared to accept the legislative objective (or at least its interpretation of it) under section 7.

With respect to disproportionate effects, this traditionally-overlooked stage of analysis took on heightened significance after the SCC's 2009 ruling in Hutterian Brethren, ${ }^{95}$ as all seven of the Court's findings of disproportionate effect came after that case, albeit always in conjunction with a "failure" under minimal impairment. It is also the stage of the section 1 analysis that is most often skipped by the Court. Two cases of particular note in which the Court found disproportionate effects are Nur and Lloyd: In both, the Court had to rely on "reasonable hypothetical cases" to invalidate Harper's mandatory minimum sentencing provisions because in neither case was the sentence "grossly disproportionate" (as required by section 12) for the actual claimant. Based only on these hypothetical scenarios, the Court

94. See e.g. Kelly, Governing with the Charter, supra note 15.

95. Alberta v Hutterian Brethren of Wilson Colony, 2009 SCC 37, 2 SCR 567. 
also found the laws had disproportionately negative effects. These rulings call into serious question then-Justice McLachlin's assertion, cited earlier, that "s. 1 is an exercise based on the facts of the law at issue ..., not on abstractions."

Before closing, it should be noted that although I have often referred to "the Court" throughout this paper, six of the nineteen cases were decided with one or more dissenting opinions, with the most divided ruling in $D B(5-4)$. St-Onge Lamoureux produced a 7-2 split, Nur and Lloyd were both divided 6-3, and Wakeling three plus one concurrence versus three dissenters. In all of these cases, the dissenting justices were in agreement with the AGC's position. Finally, in Toronto Star, the eight-justice majority agreed with the AGC and upheld the law over the sole dissent of Justice Abella. At 32 per cent (6/19), the rate of dissent in these cases is slightly higher than the Court's overall rate of 28 per cent (530/733) during the 2006-2015 Harper era. ${ }^{96}$

\section{CONCLUSIONS}

There is no question the federal government suffered a number of significant criminal-justice-policy losses at the hands of the SCC during the Harper era. Even holding the issue of case "salience" aside, measured holistically, the government lost two-thirds of the time, which is a significantly worse track record for Ottawa than found in previous (albeit not directly comparable) studies. If we measure just "cases" rather than "issues," the Conservative government won criminal law cases about as often as it lost, which is to say its success rate was still a bit lower than that of the preceding federal governments in all Charter litigation since 1982. About half of the Harper-era losses concerned laws passed by his government, most notably mandatory minimum sentencing provisions. That said, the highest-profile criminal policy losses, on prostitution and assisted death, involved laws adopted long before Prime Minister Harper took office. Most of the Charter-based challenges in this study came from section 7, which occasioned extensive government and judicial arguments about whether prima facie rights infringements were consistent with the "principles of fundamental justice," and some significant instances where the Court rejected the government's characterization of the law's objective. Once the Court moved to reasonable limits analysis under section 1, the government fared exceptionally poorly, successfully defending an impugned law only once. As expected, the usual problem under

96. Percentages calculated by the author. Supreme Court of Canada, Statistics 2005 to 2015 (Ottawa: Supreme Court of Canada, 2016) at 3. Unfortunately, figures for Charter cases only are not available. 
section 1 was a non-minimal impairment of rights, although more provocative rejections under "rational connection" and "proportionate effect" were also seen.

Pulling back from the finer details, two big themes emerge from the evidence. The first is that the government under Prime Minister Harper adopted a consistently defensive posture, conceding only a small number of free speech infringements that are practically a given in light of the jurisprudence, and never overtly conceding unreasonableness. In short, full Charter defences were the norm. This defensiveness may not surprise anyone who followed federal politics for the last decade, but Harper's fulsome defence of Liberal-era laws might. That Prime Minister Trudeau's government continued to defend a controversial Harper-era law just as vigorously might surprise them even more. It at least raises the question whether there is now an institutional directive or cultural norm in the Attorney General of Canada's office that all laws will be defended to the fullest regardless of authorship or content.

The second theme is the Court's rejection of "blanket-application" laws. Mandatory minimum sentences are perhaps the clearest example, but there are others: denying enhanced credit to everyone refused bail because of a prior conviction; denying early parole to everyone, even retroactively, regardless of their individual situation; denying everyone access to anything but dried medical marijuana, regardless of their specific health needs. A similar logic animates the invalidation in Carter of the assisted death ban, with the Court effectively carving out an exception for a narrow group of competent individuals in severe, irremediable, and intolerable suffering. So too with Federation of Law Societies, which was sparked by the Harper government's decision to end the informal exemption of law firms from financial reporting laws, with no real allowance for the unique nature of the solicitor-client relationship in that industry. Recall also that the decision to uphold the Controlled Drugs and Substances Act in the Insite case rested on the availability of an exemption from an otherwise "blanket-application" law. All of this raises the point made by James Kelly" that analyses of judicial activism must take into account the nature of the legislation in question - or to put it more bluntly, that some laws are simply poorly crafted. This is arguably a predictable outcome of heavily concentrating power in the Prime Minister's Office, as Canada has experienced in recent decades, and the concomitant weakening of careful legislative scrutiny in the House and more

97. Kelly, Governing with the Charter, supra note 15 at 239-245. 
importantly in its committees. ${ }^{98}$ That is not to suggest, however, that all of the blanket-application laws discussed herein were poorly-drafted. It was not the goal of this paper to adjudge the quality of the laws included in the study, though it can be noted that some blanket-application laws were invalidated during the Harper era on the rather flimsy basis of "reasonable hypotheticals" rather than actual problems in practice. The study does makes it clear, however, that the Court has proven itself more than willing to demand that the government defend the reasonableness of its laws, thus putting those responsible for designing legislation on notice.

98. Donald Savoie, Governing from the Centre: The Concentration of Power in Canadian Politics (Toronto: University of Toronto Press, 1999); Donald Savoie, Power: Where Is It? (Montreal: McGill-Queen's University Press, 2010); Graham White, Cabinets and Cabinet Ministers (Vancouver: UBC Press, 2006) 
